\title{
Factors Affecting the Development of the Electronic Marketing Capacity of Professional Sports Federations
}

\author{
${ }^{1}$ Rasoul Tarighi ${ }^{*},{ }^{1}$ Seyed Nasrollah Sajjadi, ${ }^{1}$ Mehrzad Hamidi, ${ }^{1}$ Mohammad Khabiri \\ ${ }^{1}$ Department of Sport Management, Faculty of Sport Sciences, University of Tehran, Tehran, Iran.
}

\begin{abstract}
Background. Information and communication Technology, allows institutions and organizations that doing their business activities and exchanges, with high speed and flexibility. In fact, electronic-commerce has created a massive revolution in Business style and global trading. Objectives. The goal of this study was identifying of Effective Factors on Development of the Electronic Marketing Capacity of Professional Sport Federations of Iran. Methods. Methodology of This study is mixed. A questionnaire, which made by the researcher, based on Likert 5 option scale, and its validity is confirmed by professionals and professors; moreover, its reliability is examined by Cronbach's alpha test (0.843). Statistics sample consist, which involve Faculty members of Marketing Management field (20 peoples) and Faculty members of Sport Management (60 people) field. Sampling method is non-random, available and purposeful. Partial least squares regression test and Fuzzy Analytic Hierarchy Process for factors Ranking are used in inferential statistics. Results. The Results Showed that factor's include, Management Factors, knowledge Management, Customer Relationship Management, Strategies, Environmental and Competitive Factors, Website features, Organizational Culture, Supply Chain Management, Brand Factors and resources, with significant Priorities respectively, were effective factor's on Electronic marketing capability of Professional Sport Iran. Also, The Results of Fuzzy Analytic Hierarchy Process Showed that factor's include, Management Factors, resources, knowledge Management, Environmental and Competitive Factors, Organizational Culture, Strategies, Supply Chain Management, Customer Relationship Management, Brand Factors and Website features were In the first place to tenth. Conclusion. According to the results, from Interview with experts in the field of study, It seems that managers of professional sports federations should Pay more attention to identified factors of electronic marketing development that Which ranked respectively had the highest impact factor (Such as management factors, resources and knowledge management).
\end{abstract}

KEY WORDS: Sport Industry, Marketing, New Tools, Electronic Activities.

\section{INTRODUCTION}

Today, sport is referred to as an industryan industry that has grown dramatically at the international level, and in turn, has brought in significant revenue. In addition, with the growth of services in other fields and professions in the sports industry, the provision of services has significantly grown (1). The managers of professional sports organizations need to be able to effectively manage challenges such as high costs, highly

*. Corresponding Author:

Rasoul Tarighi

E-mail: rasoul.tarighi@ut.ac.ir 
competitive markets, the spread of the dissatisfaction of fans and their breakdowns, and the explosive growth of new technologies in order to survive in the business sport field (2). E-marketing, in fact, refers to the convergence of all the activities of an organization in order to sell more products and services in existing platforms and cyberspace. At the moment, the larger the extent, penetration, and inclusiveness of information technology in society, the greater the number of applications that emerge based on these technologies (including e-commerce), and the bigger the driving engine of all of these issues, i.e., e-marketing, becomes (3).

Currently, the World Wide Web has become the most extensive and complex communication medium in the world. This vast collection of documents and internet pages has provided access to a wide range of information, documents, products, and services (4). Chung and Koo (2015), in a study titled "Social Media Application in Travel Information Research", found that factors such as the reliability of information, pleasure, complexity, and effort influence the perceived value of customers (5). In addition, Salavati and Hashim (2015), in a study on the adoption of websites and the way that hotels function in Iran, concluded that Iranian hotels are in the very early stages of adopting and using the Internet; using electronic commerce is unlikely to be available in the hotel industry of Iran in the near future (6).

In a study, Kanchanatanee, Suwanno, and Jarernvongrayab (2014) concluded that factors such as the perceived usefulness, adaptability, or compatibility, perceived ease of use and attitude toward the use of e-commerce affect the desire of customers to use e-marketing (7). The results of Gamboa and Gonçalves (2014)'s essay show that in relation to customers who were fans of the ZARA Garment Company on Facebook, the factors of customer satisfaction and trust were significantly related to customer loyalty (8). Radikonyana et al. (2015), in another article found that the tools used for electronic marketing in the 2010 FIFA World Cup in South Africa included items such as websites, emails, search engines, online videos, electronic newspapers, electronic journals, e- books, tagging, internet travel, Facebook, YouTube, Twitter, electronic audio files, social networking sites and Flickr, blogs, mobile sites, and mobile technology (9).

Sinkovics and Kim (2014) found that the aspects of environmental, organizational, and technological characteristics are effective on suppliers' electronic cooperation and costumers (10). In another study by Bao and Chang (2014), it was found that the sales of products of companies significantly increases through the effective use of mouth-to-mouth messaging (11). In addition, Georgi and Mink (2013), in a study on the quality of customer-to-customer interactions in the electronic space, concluded that the seven factors that comprise the range of customer interaction quality with each other in the electronic space include items such as content, security, enjoyability, quality, space, comfort, and sociality level (12). Tiago and Tiago (2012) addressed that components such as knowledge management, supply chain management, and customer relationship management are effective on the internet marketing capabilities of European companies. In addition, internet marketing capability has had a significant effect on the performance of the ecommerce market of European corporations (13).

In fact, what we have in the current condition as sports marketing in our country relies on and is restricted to the government's presence in professional and championship sports in a way that cases such as the production and the sale of sporting goods, the sale of tickets for various competitions, and cross-sectional and inadequate financial support from some sports teams have not been able to free professional sports from this strong dependence (14). Based on the aforementioned issues and given the increasing importance of electronic marketing activities in the sports industry in advanced countries, it seems that our country's professional sports federations, including the soccer, volleyball, basketball, and handball federations, do not pay adequate attention to marketing activities through electronic and cyberspaces. In addition, since the ultimate goal of this study is to create a platform for the development of e-commerce, ebusiness, and e-marketing for the country's 
professional sports, paying attention to the fact that the authorities and managers of the country's sports are not adequately focused on electronic marketing in order to achieve higher incomes and create a more relevant relationship with customers; thus, the researcher decided to identify the factors influencing the development of the e-marketing capability of professional sports federations in the country, and then, the researcher began to rank them.

\section{MATERIALS AND METHODS}

Participants. The population of the study includes faculty members in the field of marketing management and university sports management. The statistical sample consisted of faculty members of marketing management (20 people) and faculty members of sport management (60 people) from the country's universities. The sampling method of the study was non-random targeted available.

Instrument. In this research, the field and the library methods were used to collect data. In addition, the data was collected through a questionnaire. In addition, in order to collect the required data, a researcher-made questionnaire was used. It should be noted that for the questionnaire questions in each section, the recommendations of 15 faculty members for marketing and marketing sports of the country have been exchanged and its validity has been verified and approved. In order to measure the attitude of the respondents toward the research model factors in this research, the questionnaire questions were used based on a 5-point (ranking) Likert scale with five options (strongly agree, agree, I have no idea, disagree, and strongly disagree) to quantify the data. The validity of the questionnaire has been confirmed by 15 professors of marketing management and sport management of the country and by the PLS test convergent validity. The reliability of the research was also calculated using the Cronbach's alpha test. The KS test was used to determine the distribution of questionnaire data.

Statistical Analysis. To analyze the research data and the design of the research model, the PLS-SEM test was used. In addition, in the next section, inferential statistics were used to rank the identified factors that were used by the hierarchical process of fuzzy analysis. In this section, a qualitative interview was conducted with 20 professors and experts in the field of marketing management (10 people) and sports management (10 people), and the factors were ranked and paired comparisons were made among all the components of the factors. To this end, the questionnaires were first provided to the experts so that each criterion could be scored relative to the importance that they have over each other, and for this evaluation, the Chung scoring process was used. To use the fuzzy hierarchical process method, first, a pairwise matrix was created and scored by the Chung scoring method for the main factors that included 10 criteria. After forming the matrix of the pairwise comparison of the main factors, the matrix of paired comparison matrix of each of the sub-criteria of these factors were formed and solved using the fuzzy hierarchical process. Readers can refer to Chung's article (1996) for obtaining more comprehensive information on the fuzzy hierarchy analysis process.

\section{RESULTS}

Among the respondents, $86.2 \%$ of the respondents (69 people) were male and $13.8 \%$ (11 people) were female. Among the respondents, $27.5 \%$ (22 people) were in the age group of $35-40$ years and $23.8 \%$ of them (19 people) were in the age group of 30-35 years. In addition, $25 \%$ of respondents (20 people) were members of the faculty of marketing management and $75 \%$ of them (60 people) were faculty members of sports management.

Given that none of the research variables have a normal distribution, to investigate the relationship between the variables, the partial least squares method was used. In this regard, the validity of the relationship between the structures has been confirmed and as a result, the research hypotheses have been approved at a confidence level of $95 \%$ and factors such as organizational resources $(\mathrm{T}=3.124$, $\beta=0.846)$, knowledge management $(\mathrm{T}=8.902$, $\beta=0.923)$, management factors $(T=9.236$, $\beta=0.863$ ), organizational strategies $(T=7.704$, $\beta=0.814)$, supply chain management $(\mathrm{T}=4.649, \quad \beta=0.902)$, customer relationship 
management $(\mathrm{T}=8.697, \beta=0.826)$, environmental and competitive factors $(\mathrm{T}=$ $7.269, \beta=0.713)$, characteristics of the website $(\mathrm{T}=6.512, \beta=0.826)$, organizational culture $(\mathrm{T}=5.704, \beta=0.715)$, and brand factors $(T=4.127, \beta=0.702)$, are effective for the development of the e-commerce marketing in Iran (Figure 1).

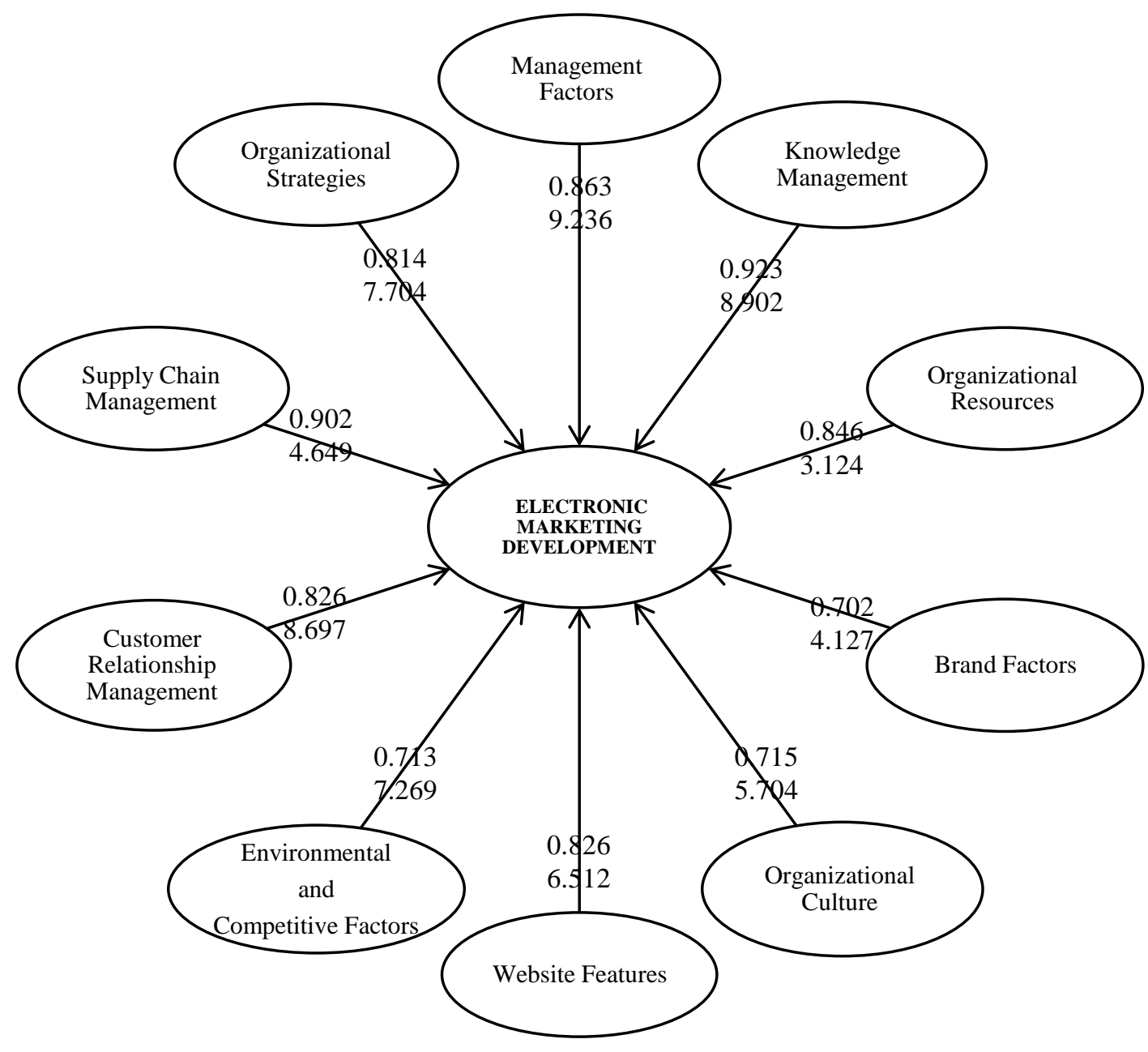

Figure 1. Structural model of the Electronic Marketing Capacity's main factors.

Table 1 shows the ranks of the Electronic Marketing Capacity's main factors and the weights of each sub-criterion of the main factors. Factors such as management factors (Rank 1, weight: 0.0788), organizational resources (Rank 2, weight: 0.0889), knowledge management (Rank 3, weight: 0.2250), environmental and competitive factors (Rank 4, weight: 0.0291), organizational culture (Rank 5, weight:
0.0937), organizational strategies (Rank 6, weight: 0.0880), supply chain management (Rank 7, weight: 0.0903), customer relationship management (Rank 8, weight: 0.0979), brand factors (Rank 9, weight: 0.0942), and website characteristics (Rank 10, weight: 0.1141) were effective for the development of the e-marketing capability in the professional sports federations of Iran with respect to their prioritization. 
Table 1. Effective factors for the development of the e-marketing capability in the professional sports federations of Iran.

\begin{tabular}{|c|c|c|c|c|c|}
\hline $\begin{array}{l}\text { Main factors } \\
\text { of } \\
\text { the research }\end{array}$ & $\begin{array}{l}\text { Factor } \\
\text { rank }\end{array}$ & $\begin{array}{l}\text { Weight of } \\
\text { the main } \\
\text { factors }\end{array}$ & Sub-criteria & $\begin{array}{l}\text { Rank below } \\
\text { the criteria }\end{array}$ & $\begin{array}{l}\text { Total weight of } \\
\text { the following } \\
\text { criteria }\end{array}$ \\
\hline \multirow{5}{*}{ Resources } & \multirow{5}{*}{2} & \multirow{5}{*}{0.0889} & $\begin{array}{l}\text { The existence of technology infrastructure in the selected } \\
\text { federations }\end{array}$ & 3 & 0.0288 \\
\hline & & & $\begin{array}{l}\text { Organizational resources: financial, human, and technical } \\
\text { resources must be available at the desired level in the } \\
\text { selected federations }\end{array}$ & 1 & 0.0186 \\
\hline & & & $\begin{array}{l}\text { The existence of appropriate hardware infrastructure in the } \\
\text { selected federations (National Infrastructure) }\end{array}$ & 2 & 0.0160 \\
\hline & & & $\begin{array}{l}\text { The status of financial funds for the selected federations } \\
\text { must be desirable }\end{array}$ & 4 & 0.0137 \\
\hline & & & $\begin{array}{l}\text { Technology orientation (having a strong network with } \\
\text { technology providers, better knowledge of technology than } \\
\text { other suppliers, designing new products based on art } \\
\text { technology) }\end{array}$ & 5 & 0.0118 \\
\hline \multirow{5}{*}{$\begin{array}{l}\text { Knowledge } \\
\text { management }\end{array}$} & \multirow{5}{*}{3} & \multirow{5}{*}{0.2250} & Knowledge should be acquired in the selected federations & 1 & 0.0185 \\
\hline & & & $\begin{array}{l}\text { Sharing knowledge must be carried out in the selected } \\
\text { federations }\end{array}$ & 4 & 0.328 \\
\hline & & & $\begin{array}{c}\text { Transfer of knowledge should be carried out in the selected } \\
\text { federations }\end{array}$ & 5 & 0.981 \\
\hline & & & $\begin{array}{c}\text { Transformation of knowledge into useful knowledge should } \\
\text { be performed in the selected federations }\end{array}$ & 2 & 0.323 \\
\hline & & & \begin{tabular}{|c|} 
Preservation of knowledge in selected federations \\
\end{tabular} & 3 & 0.434 \\
\hline \multirow[b]{2}{*}{$\begin{array}{l}\text { Management } \\
\text { factors }\end{array}$} & \multirow[b]{2}{*}{1} & \multirow[b]{2}{*}{0.0788} & $\begin{array}{c}\text { The skill levels of managers of the selected federations } \\
\text { should be appropriate }\end{array}$ & 1 & 0.03 \\
\hline & & & $\begin{array}{l}\text { The level of interest and willingness of the selected } \\
\text { federation managers to perform activities through e- } \\
\text { marketing should be high }\end{array}$ & 2 & 0.04 \\
\hline \multirow{3}{*}{ Strategies } & \multirow{3}{*}{6} & \multirow{3}{*}{0.0880} & $\begin{array}{l}\text { Electronic marketing should be compatible with the } \\
\text { strategies of the selected federations }\end{array}$ & 2 & 0.036 \\
\hline & & & $\begin{array}{l}\text { Strategic decisions or intentions (business guidance, the } \\
\text { interest of senior managers of elected federations, the } \\
\text { alignment of e-marketing with business values, and } \\
\text { alignment of innovations with values) should be emphasized }\end{array}$ & 1 & 0.035 \\
\hline & & & $\begin{array}{l}\text { Market orientation (orientation of customers and } \\
\text { competitors of the selected federations) should be } \\
\text { encouraged }\end{array}$ & 3 & 0.017 \\
\hline \multirow{7}{*}{$\begin{array}{l}\text { Supply chain } \\
\text { management }\end{array}$} & \multirow{7}{*}{7} & \multirow{7}{*}{0.0903} & $\begin{array}{l}\text { Purchasing and procurement of raw materials for the } \\
\text { provision of services by the selected federations should be } \\
\text { performed in an appropriate manner }\end{array}$ & 6 & 024121 \\
\hline & & & $\begin{array}{l}\text { The procedure of processing services by the selected } \\
\text { federations should be performed in an appropriate way }\end{array}$ & 5 & 0.012546 \\
\hline & & & $\begin{array}{l}\text { Selling and marketing operations should be carried out by } \\
\text { the appropriate federations in appropriate ways }\end{array}$ & 1 & 0.008796 \\
\hline & & & $\begin{array}{l}\text { The process of distributing products to the selected } \\
\text { federations should be performed appropriately }\end{array}$ & 2 & 0.00885 \\
\hline & & & $\begin{array}{l}\text { The supply chain integration by the appropriate federations } \\
\text { should be conducted appropriately }\end{array}$ & 7 & 0.008875 \\
\hline & & & $\begin{array}{l}\text { The sharing of mutual information by the selected } \\
\text { federations should be conducted appropriately }\end{array}$ & 8 & 0.007767 \\
\hline & & & $\begin{array}{l}\text { The establishment of appropriate distribution channels by } \\
\text { the selected federations should be carried out appropriately }\end{array}$ & 3 & 0.009367 \\
\hline
\end{tabular}


Table 1. Continued

\begin{tabular}{|c|c|c|c|c|c|}
\hline $\begin{array}{l}\text { Main factors } \\
\text { of } \\
\text { the research }\end{array}$ & $\begin{array}{c}\text { Factor } \\
\text { rank }\end{array}$ & $\begin{array}{l}\text { Weight of } \\
\text { the main } \\
\text { factors }\end{array}$ & Sub-criteria & $\begin{array}{c}\text { Rank } \\
\text { below the } \\
\text { criteria }\end{array}$ & $\begin{array}{c}\text { Total weight of } \\
\text { the following } \\
\text { criteria }\end{array}$ \\
\hline \multirow{7}{*}{$\begin{array}{l}\text { Customer } \\
\text { relationship } \\
\text { management }\end{array}$} & \multirow{7}{*}{8} & \multirow{7}{*}{0.0979} & $\begin{array}{c}\text { Establishing successful communication with customers } \\
\text { through the selected federations should be performed in } \\
\text { the appropriate manner }\end{array}$ & 3 & 0.0144 \\
\hline & & & $\begin{array}{l}\text { The orientation of the customer by the selected } \\
\text { federations should be appropriately carried out }\end{array}$ & 2 & 0.0160 \\
\hline & & & $\begin{array}{c}\text { Advertisements (via email and other online sources) by } \\
\text { the selected federations should be carried out in the } \\
\text { appropriate manner }\end{array}$ & 4 & 0.0119 \\
\hline & & & $\begin{array}{l}\text { Innovation in negotiating with customers and } \\
\text { competitors should be considered }\end{array}$ & 6 & 0.0139 \\
\hline & & & $\begin{array}{c}\text { Federations should encourage customers and motivate } \\
\text { them }\end{array}$ & 5 & 0.0115 \\
\hline & & & $\begin{array}{l}\text { Improvement of customer service should always be a } \\
\text { matter of importance for the selected federations }\end{array}$ & 7 & 0.0135 \\
\hline & & & $\begin{array}{l}\text { Awareness of the interests and the values of the } \\
\text { customers to better understand their needs should be a } \\
\text { priority for the selected federations }\end{array}$ & 1 & 0.0166 \\
\hline \multirow{4}{*}{$\begin{array}{l}\text { Environmental and } \\
\text { competitive factors }\end{array}$} & \multirow{4}{*}{4} & \multirow{4}{*}{0.0291} & $\begin{array}{c}\text { Government effect (the degree of government support, } \\
\text { market inclination, and industry pressure, background in } \\
\text { business) }\end{array}$ & 1 & 0.0050 \\
\hline & & & $\begin{array}{c}\text { Competitive environment (customers' pressure, } \\
\text { suppliers' pressure, internet usage culture, customer } \\
\text { skill levels, employee acceptance, and environmental } \\
\text { knowledge) }\end{array}$ & 3 & 0.0110 \\
\hline & & & $\begin{array}{l}\text { Electronic competitiveness (insistence of suppliers, } \\
\text { insistence of customers, investing in leading) }\end{array}$ & 2 & 0.0057 \\
\hline & & & $\begin{array}{c}\text { The intensity of the competition in the external } \\
\text { environment }\end{array}$ & 4 & 0.0073 \\
\hline \multirow{11}{*}{ Website features } & \multirow{11}{*}{10} & \multirow{11}{*}{0.1141} & $\begin{array}{c}\text { The selected federations' awareness of their website } \\
\text { should be developed in an appropriate manner (number } \\
\text { of visitors, total number of users) }\end{array}$ & 11 & 0.0086 \\
\hline & & & $\begin{array}{c}\begin{array}{c}\text { The security of the sites of the selected federations } \\
\text { should be appropriate }\end{array} \\
\end{array}$ & 5 & 0.0094 \\
\hline & & & $\begin{array}{l}\text { The design of the website of selected federations should } \\
\text { be appropriate }\end{array}$ & 4 & 0.0107 \\
\hline & & & $\begin{array}{c}\text { Perceived usefulness (the feeling of improved job } \\
\text { performance) should be understood by the staff and the } \\
\text { customers of the selected federations. }\end{array}$ & 3 & 0.0118 \\
\hline & & & $\begin{array}{c}\begin{array}{c}\text { Perceived easy application (using the system without } \\
\text { much effort) should be encouraged for the staff and } \\
\text { customers of the selected federations }\end{array} \\
\end{array}$ & 2 & 0.0091 \\
\hline & & & $\begin{array}{l}\text { The required level of trust to the site for the customers } \\
\text { of the selected federation should be provided }\end{array}$ & 9 & 0.0106 \\
\hline & & & $\begin{array}{l}\text { The site of selected federations should be easily } \\
\text { accessible }\end{array}$ & 1 & 0.0091 \\
\hline & & & $\begin{array}{l}\text { The fun and attractiveness of the site of the selected } \\
\text { federations should be desirable }\end{array}$ & 10 & 0.0095 \\
\hline & & & Buying from the selected websites should be easy & 6 & 0.0112 \\
\hline & & & $\begin{array}{l}\text { Privacy of customers in the selected federations should } \\
\text { be guaranteed }\end{array}$ & 7 & 0.0126 \\
\hline & & & $\begin{array}{l}\text { Transparency of information (on commercial and } \\
\text { market sites) should guaranteed be on the sites of the } \\
\text { selected federations }\end{array}$ & 8 & 0.0121 \\
\hline
\end{tabular}


Table 1. Continued

\begin{tabular}{|c|c|c|c|c|c|}
\hline $\begin{array}{l}\text { Main factors } \\
\text { of } \\
\text { the research }\end{array}$ & $\begin{array}{l}\text { Factor } \\
\text { rank }\end{array}$ & $\begin{array}{l}\text { Weight of the } \\
\text { main factors }\end{array}$ & Sub-criteria & $\begin{array}{l}\text { Rank below } \\
\text { the criteria }\end{array}$ & $\begin{array}{l}\text { Total weight of the } \\
\text { following criteria }\end{array}$ \\
\hline \multirow{5}{*}{$\begin{array}{l}\text { Organizational } \\
\text { culture }\end{array}$} & \multirow{5}{*}{5} & \multirow{5}{*}{0.0937} & $\begin{array}{l}\text { The inner culture of the selected federations should } \\
\text { accept the implementation of electronic marketing } \\
\text { activities }\end{array}$ & 3 & 0.0173 \\
\hline & & & $\begin{array}{l}\text { Cultural attention should be paid to the target } \\
\text { markets in the selected federations }\end{array}$ & 4 & 0.0203 \\
\hline & & & $\begin{array}{l}\text { The attitude of employees and managers of the } \\
\text { selected federations toward the use of e-commerce } \\
\text { should be positive }\end{array}$ & 1 & 0.0161 \\
\hline & & & $\begin{array}{l}\text { Shared values and good behavior by the employees } \\
\text { and managers of the selected federations should be } \\
\text { encouraged }\end{array}$ & 2 & 0.0178 \\
\hline & & & $\begin{array}{l}\text { A cultural orientation toward the use of electronic } \\
\text { marketing by the selected federations should be } \\
\text { encouraged }\end{array}$ & 5 & 0.0222 \\
\hline \multirow{3}{*}{ Brand factors } & \multirow{3}{*}{9} & \multirow{3}{*}{0.0942} & $\begin{array}{l}\text { A particular value of the brand for the selected } \\
\text { federations should be desirable }\end{array}$ & 2 & 0.0208 \\
\hline & & & $\begin{array}{l}\text { The brand image of the selected federations should } \\
\text { be appropriate in the minds of the customers }\end{array}$ & 1 & 0.0496 \\
\hline & & & $\begin{array}{l}\text { The brand imagination of the selected federations } \\
\text { should be desirable for our customers }\end{array}$ & 3 & 0.0238 \\
\hline
\end{tabular}

\section{DISCUSSION}

The aim of this study was to identify the effective factors that have an impact on the development of electronic marketing of professional sports federations in the country. The results showed that in the order of prioritization of the significance of management factors, knowledge management, customer relationship management, strategies, environmental and competitive factors, website features, organizational culture, supply chain management, brand factors, and resources are the variables which affect the e-marketing capabilities of professional sports in Iran.

The results of the research have shown that the factor of the organization's resources affects the development of the e-marketing capability of the professional sport of the country. Therefore, it can be argued that the selected professional sports federations of the country should develop their own technology infrastructure as well as motivate proper organizational, human, and technical resources in these federations. The results of the research by Anche, Hozouri, and Mehdizadeh (2014) are also consistent with the present study (15).

In addition, according to the results of the research, the knowledge management factor has an effect on the development of the e-marketing capability of professional sports in the country. In the field of knowledge management, it can be stated that professional sports federations should pay attention to activities such as gaining knowledge, sharing knowledge, transferring knowledge, transforming knowledge into useful knowledge, and maintaining knowledge in their organizations. Tiago and Tiago (2012) also obtained similar results in an article (13).

On the other hand, the results showed that the component of management factors affects the development of the e-marketing capability of professional sports in the country. It seems that the level of interest and willingness, and the skills and expertise of the managers of professional sports federations should be high to perform activities through e-commerce. The results of this study are consistent with the results of the studies of Mzee, Ogweno and Irene (2015), and Fu et al. (2006) (16, 17).

In addition, it was found that the factor of organizational strategies affects the development of the e-marketing capability of professional sports in the country. In this regard, it can be stated that the concept of e-marketing should demonstrate necessary adaptation and coordination in providing the organizational 
strategies, goals, and missions of professional sports federations. It should also direct and encourage customers and competitor federations to take advantage of these services. Rady, Mohssen Elshreef, and Abd-el-Kader (2010), and Varadarajan and Yadav (2009) also found similar results to the results of this research $(18$, 19).

In addition, the results indicated that the supply chain management factor affects the development of the e-marketing capability of the country's professional sports. As a result, it seems that professional sports federations need to pay enough attention toward the procurement of raw materials for the provision of services, the processing of services, sales and marketing operations, the process of distributing products and services, and the establishment of appropriate distribution channels, mutual information sharing, integration of the supply chain, and the creation and maintenance of longterm relationships with suppliers. The results of the present study are consistent with the results of Chong, Bian, and Zhang (2015) and Tiago and Tiago (2012) $(13,20)$.

Furthermore, the results of the research showed that customer relationship management has an impact on the development of the emarketing capability of professional sports in the country. In this case, it seems that the selected professional sports federations should try to establish a successful and effective relationship with their customers and direct customers to use electronic services, and broaden email and online advertising. Chong, Bian, and Zhang (2015), and Tsiotsou and Vlachopoulou (2011) also came to conclusions in line with the results of this research $(20,21)$.

The findings of this study showed that environmental and competitive factors affect the development of the e-marketing capability of professional sports in the country. In this regard, it can be said that the selected professional sports federations should focus on environmental factors such as the level of government support, market inclination and industry pressure, customer pressure, suppliers' pressure, customer and employee skills, and the culture of using the Internet. Mzee, Ogweno and Irene (2015) also found results that were consistent with the results of this study (17).
In addition, based on these results, the factor of website characteristics affects the development of e-marketing and e-commerce in the country. Therefore, it seems that the level of awareness of the federations from the total number of users and site visitors should be sufficient and their sites should have the trust they require from the customers' point of view. In addition, professional sports federations should have a website with features such as proper design, high perceived usefulness for customers, availability, ease of usage, customer privacy, and ease of purchase for customers and employees. The results of this study are consistent with the results of Saliani, Lagzian and Maghool (2013), and Sehhat (2012) (22, 23).

According to these results, organizational culture affects the development of the emarketing capability of professional sports in the country. In this regard, it can be argued that the managers and the staff of federations should have a positive attitude and a suitable culture for the adoption and the performance of electronic marketing activities, and perform cultural orientation for the use of e-services for employees and customers. El-Gohary (2012) also found similar results to the results of this study (24).

Finally, according to the results of this research, brand factors affect the development of the e-marketing capability of the professional sports in the country. In this regard, it seems that professional sports federations should consider developing factors such as their specific brand value, a good image of their brand, and they should create an appropriate association of their brand in the minds of customers. Saliani, Lagzian and Maghool (2013) found similar results in a study (22).

\section{CONCLUSION}

The present results were based on responding to the question of why professional sports federations do not pay attention to the use of new marketing tools. In order to find the answer to the main research question, the researcher decided to identify factors influencing the development of the e-marketing capability by carefully studying domestic and foreign researches related to research in the sports industry and other industries. After extracting 
the factors and the sub-factors of studies from foreign investigations and obtaining confirmation of the validity of the factors from the corresponding experts, the factors were identified through a distribution of a researchermade questionnaire and the use of the quasisquares method; these factors were then ranked by a qualitative interview with the experts and the factors were ranked using the method of the process of fuzzy hierarchy analysis. The innovation of this research was that until this point, no research had been conducted on the concept of e-marketing in the country's sports industry, especially, with regard to professional sports federations. The ranking test results have shown that factors such as management factors, organizational resources, and knowledge management have the greatest importance in the electronic marketing development of professional sports federations. Factors such as customer relationship management, brand features, and site features were in the last rankings. According to the findings of this research, it is suggested that managers of professional sports federations of our country should try to reconstruct the technological infrastructure of the federations and preserve the knowledge gained in their organization. In addition, these federations should try to use powerful and skilled managers adept at using new e-marketing tools, and moreover, regulate their federations' strategies for the use of electronic marketing. In addition, based on the research findings, it can be suggested that these federations should direct customers toward the use of e-services and focus on environmental factors such as government support, customer pressure, and supplier pressure. On the other hand, it is suggested that professional sports federations should have a website with features such as appropriate design with a high level of perceived usefulness for customers, accessibility, and ultimately, these federations should be able to deal with the development of brand value and brand image in the minds of their customers through the performance of promotional and advertising activities. In addition, to conduct this study, there were limitations such as the lack of adequate research background within the country and the lack of easy access to research samples. Finally, considering the necessary point that, so far, no research has been conducted in the field of electronic marketing in Iran's professional sports federations, the results of this study cannot be compared with another study, and the need for more research and further studies in this field is obvious. Therefore, it is suggested that studies be conducted on identifying barriers to the development of electronic marketing in the country's professional sports federations.

\section{APPLICABLE REMARKS}

- The use of new marketing tools will allow professional sports federations to spend less on costs, carry out activities related to the development of technology infrastructure and establish more effective communication with their staff, market, suppliers, and customers through the site and electronic devices.

- The use of electronic marketing technologies will increase the income generation of professional sports federations significantly and this will reduce their dependence on the general funds supplied by the government.

- Performing e-marketing activities in professional sports federations will create a culture of using the Internet and a positive culture in the use of eservices in the sports industry; it will also improve the specific brand value and brand image of the mentioned federations.

\section{REFERENCES}

1. Rajabi H, Tarighi R, Mizany M. The Study of Customer experiences and satisfaction of service in Aquatic sports clubs. Applied Research of Sport Management 2016;4(15):67-78 [Article in Farsi]. 
2. Tarighi R, Hamidi M, Rajabi H. Designing Sport Marketing Model of National University Sport Federation of Ir. Iran. Journal of Research on University Sport. 2014;2(5):15-30 [Article in Farsi].

3. Pitt PBL, Watson RT. Marketing Communication And The World Wide Web. Business Horizons. 1996;39(5):2432.

4. Ioakimidis M. Online marketing of professional sports clubs: engaging fans on a new playing field. International Journal of Sports Marketing and Sponsorship. 2010;11(4):2-13.

5. Chung N, Koo C. The use of social media in travel information search. Telematics and Informatics. 2015;32(2):215-29.

6. Salavati S, Hashim NH. Website adoption and performance by Iranian hotels. Tourism Management. 2015;46:367-74.

7. Kanchanatanee K, Suwanno N, Jarernvongrayab A. Factors affecting the intention to use E-marketing of small and medium sized businesses in the three southern border provinces of Thailand. International Journal of Business and Social Science. 2014;5(6).

8. Gamboa AM, Gonçalves HM. Customer loyalty through social networks: Lessons from Zara on Facebook. Business Horizons. 2014;57(6):709-17.

9. Radikonyana PS, Heath E, Fairer-Wessels FF-W, Prinsloo J, Pelser TG. A strategic e-marketing framework for sport mega-events. Journal of Applied Business Research. 2015;31(2):437-54.

10. Sinkovics RR, Kim D. The impact of technological, organizational and environmental characteristics on electronic collaboration and relationship performance in international customer-supplier relationships. Information \& Management. 2014;51(7):854-64.

11. Bao T, Chang T-1S. Finding disseminators via electronic word of mouth message for effective marketing communications. Decision Support Systems. 2014;67:21-9.

12. Georgi D, Mink M. eCCIq: The quality of electronic customer-to-customer interaction. Journal of Retailing and Consumer Services. 2013;20(1):11-9.

13. Tiago MT, Tiago F. Revisiting the Impact of Integrated Internet Marketing on Firms' Online Performance: European Evidences. Procedia Technology. 2012;5:418-26.

14. Tarighi R, Hamidi M, Rajabi H. Identifying Effective Factors in Development of Sport Marketing in University Sport of I.R. Iran. Sport Management Studies. 2017;8(40):113-30 [Article in Farsi].

15. Anche F, Hozouri S, Mehdizadeh A. An exploration investigation on important factors influencing e-marketing: Evidence from banking industry. Uncertain Supply Chain Management. 2014;2(1):49-54.

16. Fu HP, Ho YC, Chen RC, Chang TH, Chien PH. Factors affecting the adoption of electronic marketplaces: A fuzzy AHP analysis. International Journal of Operations \& Production Management. 2006;26(12):1301-24.

17. Mzee RM, Ogweno KL, Irene N. Factors influencing Adoption of E marketing by small and Medium Enterprises (SMEs) in Kisumu Municipality. IOSR Journal of Business and Management (IOSR-JBM). 2015;17(5):78-83.

18. Rady BA, Mohssen Elshreef AM, Abd-el-Kader AF. The Electronic Marketing and Services Quality in Sports Clubs. World Journal of Sport Sciences. 2010;3(8):804-15.

19. Varadarajan R, Yadav MS. Marketing strategy in an internet-enabled environment: a retrospective on the first ten years of JIM and a prospective on the next ten years. Journal of Interactive Marketing. 2009;23(1):11-22.

20. Chong WK, Bian D, Zhang N. E-marketing services and e-marketing performance: the roles of innovation, knowledge complexity and environmental turbulence in influencing the relationship. Journal of Marketing Management. 2016;32(1-2):149-78.

21. Tsiotsou RH, Vlachopoulou M. Understanding the effects of market orientation and e-marketing on service performance. Marketing Intelligence \& Planning. 2011;29(2):141-55.

22. Saliani S, Lagzian M, Maghool A. The effect of electronic marketing mix on the willingness of customers to buy online (Case study: Universities of Mashhad). International Journal of Advanced Studies in Humanities and Social Science. 2013;1(9):1254-60.

23. Sehhat S. An empirical survey to measure the impact of different factors on the success of electronic marketing. Management Science Letters. 2012;2(6):2187-92.

24. El-Gohary H. Factors affecting E-Marketing adoption and implementation in tourism firms: An empirical investigation of Egyptian small tourism organisations. Tourism Management. 2012;33(5):1256-69. 